Claremont Colleges

Scholarship@ Claremont

All HMC Faculty Publications and Research

HMC Faculty Scholarship

$1-1-1994$

\title{
Moderate Dehydration Decreases Locomotor Performance of the Ghost Crab, Ocypode quadrata
}

Randi B. Weinstein

University of Arizona

Robert J. Full

University of California - Berkeley

Anna N. Ahn

Harvey Mudd College

\section{Recommended Citation}

Weinstein, R.B., Full, R.J. and Ahn, A.N. 1994. "Moderate dehydration decreases locomotor performance of the ghost crab, Ocypode quadrata." Physiol. Zool. 67: 873-891.

This Article is brought to you for free and open access by the HMC Faculty Scholarship at Scholarship @ Claremont. It has been accepted for inclusion in All HMC Faculty Publications and Research by an authorized administrator of Scholarship @ Claremont. For more information, please contact scholarship@cuc.claremont.edu. 


\title{
Moderate Dehydration Decreases Locomotor Performance of the Ghost Crab, Ocypode quadrata
}

\author{
Randi B. Weinstein* \\ Robert J. Full \\ Anna N. Ahn \\ Department of Integrative Biology, University of California, Berkeley, California \\ 94720
}

Accepted 1/25/94

\begin{abstract}
The effect of debydration on the aerobic metabolism and endurance of sustained, terrestrial locomotion was determined for the ghost crab, Ocypode quadrata. The rate of evaporative water loss, measured as the percentage of decrease in body mass per bour, was influenced by ambient temperature $\left(\mathrm{T}_{a}\right)$. Increasing $\mathrm{T}_{a}$ from $24^{\circ} \mathrm{C}$ to $30^{\circ} \mathrm{C}$ (40\%-50\% relative bumidity) increased the rate of water loss from $2.3 \% b^{-1} \pm 0.2 \% b^{-1}$ to $3.6 \% b^{-1} \pm 0.6 \% b^{-1}$. Crabs were divided into three treatment groups to determine the effect of debydration on aerobic metabolism: bydrated control crabs, slowly debydrated crabs, and rapidly debydrated crabs. Hydrated control crabs lost only $1.2 \%$ of their initial body mass. Slowly debydrated crabs were debydrated by $3.6 \%$ of their initial body mass at a rate of $2.3 \% b^{-1}$. Finally, rapidly debydrated crabs were debydrated by $3.6 \%$ of their initial body mass at a rate of $3.6 \% b^{-1}$. The maximal rate of oxygen consumption $\left(\dot{V}_{O_{2} \text { max }}\right)$ determined during treadmill exercise was decreased by $30 \%$ for slowly debydrated crabs and by $70 \%$ for rapidly debydrated crabs, as compared to bydrated controls. The minimum cost of locomotion was independent of the debydration state for bydrated and slowly debydrated crabs but was 62\% lower for rapidly debydrated crabs. Endurance was correlated with the speed at wbich $\dot{V}_{\mathrm{O}_{2} \text { max }}$ was attained (the maximum aerobic speed [MAS]). The MAS was bighest for bydrated control crabs and was decreased by $32 \%$ for slowly debydrated crabs and by $68 \%$ for rapidly debydrated crabs. We conclude that moderate debydration can substantially decrease the ghost crab's capacity for sustained, terrestrial locomolion.
\end{abstract}

\section{Introduction}

Numerous studies have reported negative effects of dehydration on locomotor performance (Gatten, Miller, and Full 1992). Yet, no general model

\footnotetext{
* To whom correspondence should be addressed.
} 
of the effect of dehydration on aerobic capacity, endurance, and the metabolic cost of locomotion has emerged. At present, it is not possible to predict with confidence alterations in submaximal oxygen consumption at low speeds, the increase in oxygen consumption with speed, or the speed at which maximal oxygen consumption is attained, but only that, at some level of dehydration, maximal oxygen consumption and endurance will decline. Moreover, the level of dehydration that results in a decrease in performance appears highly variable.

Amphibians and several species of semiterrestrial crabs lose water at comparable rates (Herreid 1969b; Wygoda 1984). While semiterrestrial crabs may die after losing only $10 \%-30 \%$ body wreight by dehydration (Bliss 1968 ; Herreid 1969b; Greenaway 1988), amphibians tolerate these levels of dehydration and may even perform with near normal capacity (Stefanski, Gatten, and Pough 1989). In amphibians, substantial decreases in aerobic capacity and endurance are observed only after severe dehydration ( $>10 \%-$ $20 \%$ of body weight; Gatten 1987; Moore and Gatten 1989; Preest and Pough 1989; Stefanski et al. 1989).

Semiterrestrial crabs possess several behavioral and rather novel physiological mechanisms to both retain and obtain water, which is consistent with their sensitivity to water loss (Wolcott 1988). Behavioral mechanisms to reduce water loss include building burrows that extend below the water table, foraging primarily at night when the relative humidity is high, becoming active after a rainfall, and entering the sea to moisten their gills (Williams 1965).

Physiological mechanisms that limit net water loss are particularly interesting in ghost crabs, because they have high rates of evaporative water loss as compared to other semiterrestrial crabs (Herreid 1969b). Water loss can be decreased in ghost crabs by modifying urine extrarenally (Wolcott and Wolcott 1991). Water uptake can be increased by extracting moisture from damp sand through hydrophilic setal tufts at the base of the walking legs (Wolcott 1976, 1984). Reliance on water extraction may restrict ghost crabs to sandy soil, where the water table is close to the surface. Our companion article (Weinstein and Full 1994) confirmed the importance of evaporative water loss in ghost crabs. We discovered that evaporative cooling maintains body temperature $\left(T_{\mathrm{b}}\right)$ at $6^{\circ} \mathrm{C}$ below high ambient temperatures $\left(T_{\mathrm{a}}\right.$ ) (i.e., at $30^{\circ}-35^{\circ} \mathrm{C}$ ), which avoids the $75 \%$ decrease in maximal oxygen consumption associated with high body temperature. In the field, crabs foraging nocturnally at relative humidities ranging from $57 \%$ to $95 \%$ have body temperatures of $17^{\circ}-28^{\circ} \mathrm{C}$ (air temperature range $=19^{\circ}-28^{\circ} \mathrm{C} ; \mathrm{R}$. B. Weinstein, unpublished data), which indicates that evaporative cooling occurs even at night. What remains unclear is the extent to which the accompanying dehydration affects locomotor performance. 
In the present study, we attempt to augment the general model relating aerobic capacity to endurance and the metabolic cost of locomotion by including dehydration. We selected the ghost crab, ocypode quadrata, because of its apparent high rate of water turnover (Greenaway 1988). We hypothesize, as we did with high temperature in our companion article (Weinstein and Full 1994), that dehydration will reduce maximal oxygen consumption, the speed at which maximal oxygen consumption is attained (maximum aerobic speed [MAS]), and endurance. Because we propose to quantify workload (i.e., speed) during ghost crab locomotion, we will be able to attribute a decrease in maximal oxygen consumption or endurance to the effect of dehydration and not simply a decline in effort or activity intensity. Finally, we will discuss the magnitude of the trade-off in performance between tolerating the effects of high body temperature versus experiencing the dehydration that reduces body temperature.

\section{Material and Methods}

\section{Animals}

Ghost crabs, Ocypode quadrata (mass, $29.2 \mathrm{~g} \pm 9.2 \mathrm{~g}$ [mean $\pm 1 \mathrm{SD}$ ]; $n$ $=48$ ), were collected in Beaufort, North Carolina, transported to our laboratory, and maintained as described in Weinstein and Full (1994).

\section{Evaporative Water Loss}

The average rate of change in body mass was determined for crabs resting in a miniature Plexiglas chamber. The chamber was placed in an incubator (Fisher Low Temperature Incubator, Model 146) to control $T_{\mathrm{a}}$ at $15^{\circ}, 24^{\circ}$, $30^{\circ}$, or $35^{\circ} \mathrm{C}(40 \%-50 \%$ relative humidity $[\mathrm{RH}])$. At a $T_{\mathrm{a}}$ of $30^{\circ} \mathrm{C}$, ghost crabs were also exposed to $99 \% \mathrm{RH}$. The flow rate (FR) through the chamber was $200 \mathrm{~mL} \mathrm{~min}^{-1}$. Crabs were weighed before being placed in the chamber to obtain initial mass $\left(M_{\mathrm{i}}\right)$ and after being removed from the chamber to obtain final mass $\left(M_{f}\right)$. Crabs were not blotted dry before being weighed and placed in the chamber. On the basis of earlier metabolic studies (Weymouth et al. 1944; Scholander et al. 1953), Herreid (1969b) estimated that weight loss due to carbon loss was less than $1 \%$ of the total weight loss for brachyuran crabs. Therefore, the difference in body mass was assumed to be the result of water loss due to evaporation. The total amount of time the crab rested in the chamber was recorded $\left(T_{\mathrm{tot}}\right)$. The average rate of evaporative water loss (EWL), that is, the percentage of the initial mass lost per hour, was calculated from the equation 


$$
\mathrm{EWL}=\left(M_{\mathrm{i}}-M_{\mathrm{f}}\right) 100 M_{\mathrm{i}}^{-1} T_{\text {tot }}^{-1}
$$

where $M_{\mathrm{i}}$ and $M_{\mathrm{f}}$ were measured to $0.01 \mathrm{~g}$, and $T_{\text {to }}$ was the elapsed time in hours.

\section{Hemolymph Osmolality}

To examine the effect of dehydration on total hemolymph osmolality, blood samples $(0.5 \mathrm{~mL})$ were taken before and after $1 \mathrm{~h}$ of exposure to a $T_{\mathrm{a}}$ of $30^{\circ} \mathrm{C}(40 \%-50 \% \mathrm{RH})$. The total osmolality of each hemolymph sample was measured in duplicate with a vapor pressure osmometer (Model 5500, Wescor). The total osmolality of the $30 \%-50 \%$ seawater in each crab's housing container was also measured in duplicate. Samples were kept on ice to minimize clotting and were analyzed within 5 min of being withdrawn from the animal.

\section{Aerobic Metabolism: Debydration Treatment}

Crabs were divided into three treatment groups. These groups are referred to as (1) hydrated control crabs, (2) slowly dehydrated crabs, and (3) rapidly dehydrated crabs. The hydrated crabs rested in the treadmill chamber for $30 \mathrm{~min}$ at a $T_{\mathrm{a}}$ of $24^{\circ} \mathrm{C}$ prior to data collection. Thirty minutes is the minimum amount of time required to achieve a stable resting metabolic rate. The airflow rate was $300 \mathrm{~mL} \mathrm{~min}{ }^{-1}$, and $\mathrm{RH}$ was $40 \%-50 \%$. When exposed to these conditions, the crabs had a $T_{\mathrm{b}}$ of approximately $24^{\circ} \mathrm{C}$ (Weinstein and Full 1994) and were expected to lose water at a rate of $2.4 \%$ of their initial body mass per hour (see Results). Data for the hydrated control crabs are from Full (1987) and were replicated in the present group of animals.

The slowly dehydrated crabs rested in the treadmill chamber for $90 \mathrm{~min}$ at a $T_{\mathrm{a}}$ of $24^{\circ} \mathrm{C}$ prior to data collection $\left(\mathrm{FR}=300 \mathrm{~mL} \mathrm{~min}{ }^{-1} ; \mathrm{RH}=40 \%-\right.$ $50 \%$ ). When exposed to these conditions, the crabs had a $T_{\mathrm{b}}$ of approximately $24^{\circ} \mathrm{C}$ (Weinstein and Full 1994) and were expected to lose water at a rate of $2.4 \%$ per hour (see Results). The only difference between the hydrated and slowly dehydrated crabs was the duration of the rest period prior to data collection.

The rapidly dehydrated crabs rested for $60 \mathrm{~min}$ at a $T_{\mathrm{a}}$ of $30^{\circ} \mathrm{C}(\mathrm{FR}=200$ $\left.\mathrm{mL} \min ^{-1} ; \mathrm{RH}=40 \%-50 \%\right)$ prior to data collection. Under these conditions, $T_{\mathrm{b}}$ was approximately $24^{\circ} \mathrm{C}$ (see Weinstein and Full 1994), and the crabs were expected to lose water at a rate of $3.6 \%$ per hour (see Results). By increasing the $T_{\mathrm{a}}$, we increased the rate of dehydration while maintaining $T_{\mathrm{b}}$ at $24^{\circ} \mathrm{C}$. 
All crabs were weighed before being placed in the treadmill chamber to determine the initial body mass. As in the EWL experiments, crabs were not blotted dry before being placed in the treadmill chamber. Each crab was weighed again after the oxygen consumption measurements were completed and the total elapsed time was recorded. The average rate of water loss was calculated for each animal according to the equation described previously.

Measurements of resting metabolic rate, steady state oxygen consumption $\left(\dot{V}_{2 s s}\right)$, maximal rate of oxygen consumption $\left(\dot{\mathrm{V}}_{2} \mathrm{O}_{\mathrm{max}}\right)$, and endurance were made as described in Weinstein and Full (1994).

\section{Results}

Evaporative Water Loss

The average rate of water loss was influenced by ambient temperature (fig. 1). The rate of water loss was similar for crabs exposed to $T_{\mathrm{a}}^{\prime}$ 's of $15^{\circ} \mathrm{C}(n$ $=6)$ and $24^{\circ} \mathrm{C}(n=6$; Mann-Whitney $U$-test, $P>0.05)$. Crabs exposed to a $T_{\mathrm{a}}$ of $30^{\circ} \mathrm{C}(40 \%-50 \% \mathrm{RH})$ had significantly higher rates of water loss ( $n$

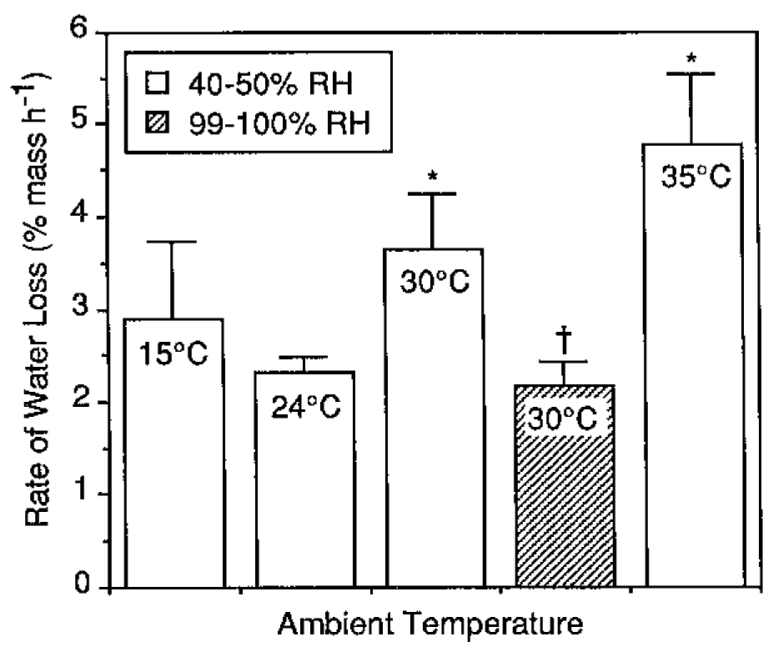

Fig. 1. Rate of water loss as a function of $\mathrm{T}_{a}$ and RH. The average rate of water loss is plotted for each $\mathrm{T}_{a}$. Error bars represent $1 \mathrm{SE}$. Crabs resting at a $\mathrm{T}_{a}$ of $24^{\circ} \mathrm{C}$ bad lower rates of water loss than crabs resting at $a \mathrm{~T}_{a}$ of $30^{\circ} \mathrm{C}(40 \%-50 \% \mathrm{RH})$. An increase in relative bumidity decreased the rate of water loss for crabs resting at a $\mathrm{T}_{a}$ of $30^{\circ} \mathrm{C}$. An asterisk (") indicates that the rate of water loss was significantly different from the rate of water loss at $24^{\circ} \mathrm{C}$. A dagger ( $H$ ) indicates that the rate of water loss was significantly different from the rate of water loss at $30^{\circ} \mathrm{C}(40 \%-50 \% \mathrm{RH})$. 
$=6$; Mann-Whitney $U$-test, $P<0.05)$ than crabs at a $T_{\mathrm{a}}$ of $24^{\circ} \mathrm{C}$. The rates of water loss measured at $T_{\mathrm{a}}$ 's of $30^{\circ} \mathrm{C}$ and $35^{\circ} \mathrm{C}(n=6)$ were not significantly different from one another (Mann-Whitney $U$-test, $P>0.05$ ). Exposure to 99\%-100\% RH decreased the rate of water loss at a $T_{\mathrm{a}}$ of $30^{\circ} \mathrm{C}$ as compared to $40 \%-50 \% \mathrm{RH}$ and a $T_{\mathrm{a}}$ of $30^{\circ} \mathrm{C}(n=6$; Mann-Whitney $U$-test, $P<0.05)$.

\section{Hemolymph Osmolality}

Total hemolymph osmolality was not affected by 60 min of dehydration at a $T_{\mathrm{a}}$ of $30^{\circ} \mathrm{C}$ and $40 \%-50 \% \mathrm{RH}$. The average initial hemolymph osmolality (831 mosm $\mathrm{kg}^{-1} \pm 9$ mosm $\mathrm{kg}^{-1}$ ) was not significantly different from the average final hemolymph osmolality ( 849 mosm kg-1 \pm 8 mosm kg-1; $n$ $=6$; paired $t$ test, $P=0.17$ ). The total osmolality of the $30 \%-50 \%$ seawater in the ghost crab housing containers was 397 mosm kg-1 \pm 2 mosm kg-1 $(n=6)$.

\section{Aerobic Metabolism}

Debydration State. The hydrated control crabs were exposed to a $T_{\mathrm{a}}$ of $24^{\circ} \mathrm{C}$ and $40 \%-50 \%$ RH. The average rate of water loss for crabs exposed to these conditions was $2.3 \% \mathrm{~h}^{-1} \pm 0.2 \% \mathrm{~h}^{-1}$. If it is assumed that the rate of water loss was constant, these crabs were dehydrated by $1.2 \%$ of their initial body mass at the end of the 30-min dehydration period.

The slowly dehydrated crabs were also exposed to a $T_{\mathrm{a}}$ of $24^{\circ} \mathrm{C}$ and $40 \%-$ $50 \%$ RH. These crabs had an average rate of water loss of $2.4 \% \mathrm{~h}^{-1} \pm 0.3 \%$ $\mathrm{h}^{-1}$ and were dehydrated by $3.5 \% \pm 0.3 \%$ of their initial body mass after the 90-min dehydration period.

The rapidly dehydrated crabs were exposed to a $T_{\mathrm{a}}$ of $30^{\circ} \mathrm{C}$ and $40 \%-50 \%$ RH. These crabs had an average rate of water loss of $3.6 \% \mathrm{~h}^{-1} \pm 0.6 \% \mathrm{~h}^{-1}$. and were dehydrated by $3.6 \% \pm 0.6 \%$ after the 60 -min dehydration period. The amount of dehydration at the end of the dehydration period was not significantly different for the slowly and rapidly dehydrated crabs (MannWhitney $U$-test, $P>0.05)$. However, the crabs exposed to a $T_{\mathrm{a}}$ of $30^{\circ} \mathrm{C}$ lost water at a faster rate than those at a $T_{\mathrm{a}}$ of $24^{\circ} \mathrm{C}$.

Resting Oxygen Consumption. The rate of oxygen consumption during the 10-min rest period prior to exercise was averaged to obtain $\dot{\mathrm{V}}_{2}$ rest. Massspecific $\dot{V}_{\mathrm{O}_{2} \text { rest }}$ was significantly lower $(n=12$; Mann-Whitney $U$-test, $P$ $<0.05)$ for slowly dehydrated crabs than for both hydrated crabs $(n=5)$ and rapidly dehydrated crabs $(n=5$; Mann-Whitney $U$-test, $P<0.05$; table 1). All three groups of animals had similar body temperatures $\left(24^{\circ} \mathrm{C}\right.$; see Weinstein and Full 1994). 


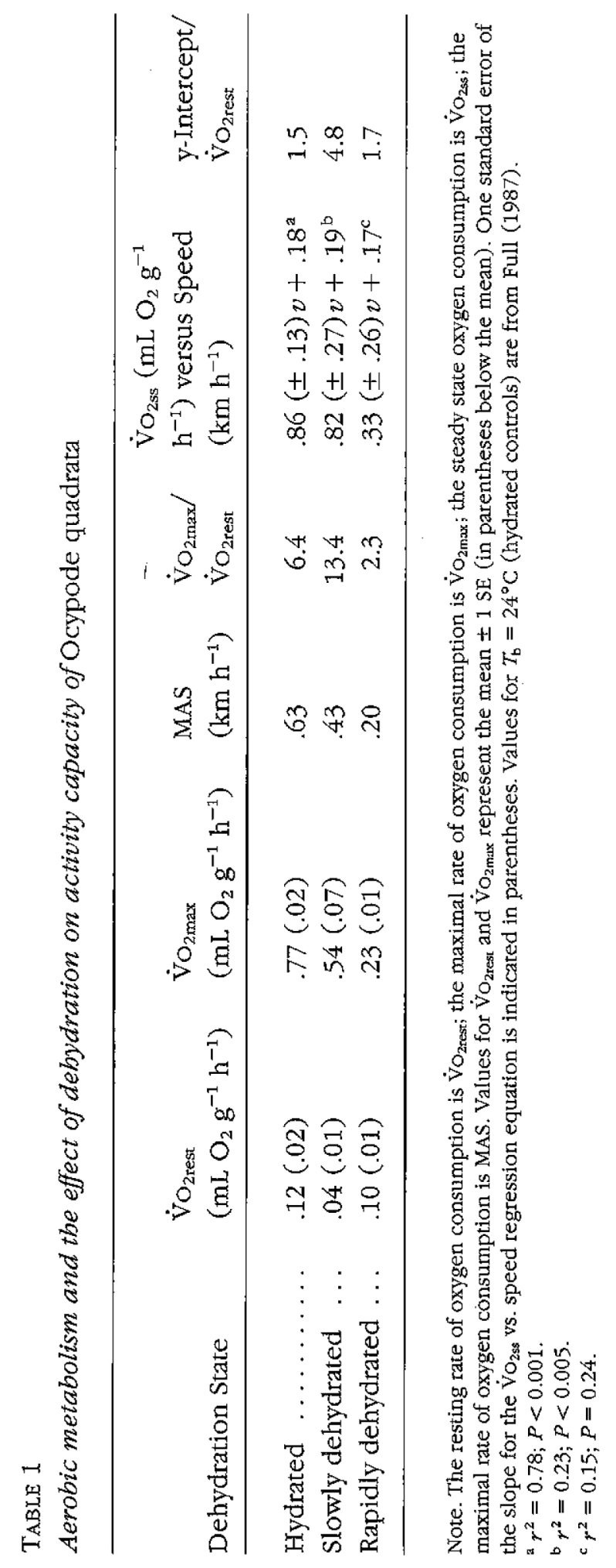


Steady State Oxygen Consumption versus Speed and the Minimum Cost of Locomotion. The steady state rate of oxygen consumption was calculated by averaging the $\dot{V}_{2}$ for the last $3 \mathrm{~min}$ of exercise at each speed. The steady state rate of oxygen consumption increased linearly with speed for crabs held at a $T_{\mathrm{a}}$ of $24^{\circ} \mathrm{C}$ (both the hydrated and slowly dehydrated crabs; fig. 2 ). The slope of the regression equation, which represents the minimum amount of metabolic energy necessary to move $1 \mathrm{~g}$ of crab $1 \mathrm{~km}$ ( $C_{\mathrm{mln}}$; Taylor, Schmidt-Nielsen, and Raab 1970), was not significantly different for hydrated crabs or for crabs slowly dehydrated at a $T_{a}$ of $24^{\circ} \mathrm{C}$ (model, $\dot{\mathrm{VO}_{2}}$ $=$ constant + temperature + speed + temperature $\times$ speed $F_{(1,44)}=0.01, P$ $>0.05$; fig. 2 ; table 1 ). The ratio of the $y$-intercept to $\dot{V}_{\mathrm{O}_{2} \text { sest }}$ for the slowly dehydrated crabs was 4.8 -fold, which is more than twice the value found for hydrated crabs. The high $y$-intercept $/ \mathrm{V}_{2}$ rest ratio for the slowly dehy-

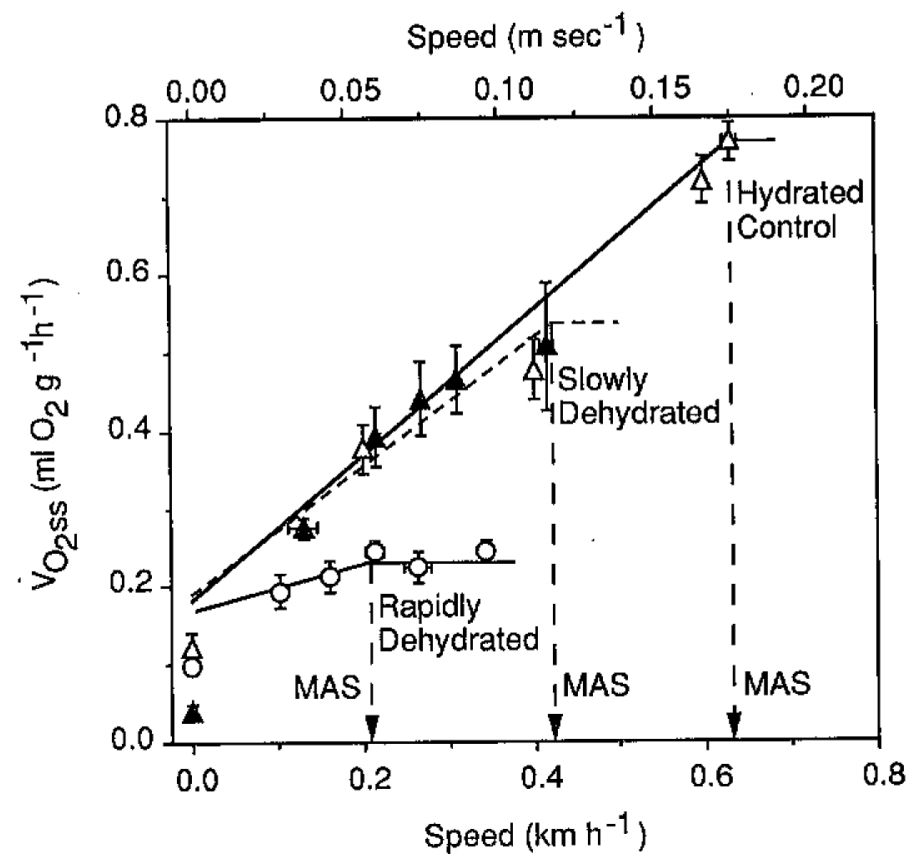

Fig. 2. Steady state oxygen consumption and $\dot{V}_{2}$ max as a function of speed for bydrated controls (open triangles), slowly debydrated crabs (closed triangles, dasbed line), and rapidly debydrated crabs (open cir. cles). Error bars represent 1 SE. For all crabs, $\mathrm{T}_{b}=24^{\circ} \mathrm{C}$. The ambient temperature for bydrated controls and slowly debydrated crabs was $24^{\circ} \mathrm{C}$, whereas for rapidly debydrated crabs $\mathrm{T}_{a}$ was $30^{\circ} \mathrm{C}$. Resting rates are sbown at zero speed. Dasbed arrows show the MAS. The data for bydrated controls are taken from Full (1987), where $\dot{V}_{2}{ }_{\text {max }}$ and MAS were determined by a step test with small incremental increases in speed. 
drated crabs may be explained by the low $\dot{\mathrm{V}}_{2}$ rest rather than by an elevated y-intercept. At submaximal exercise speeds, $\dot{V}_{O_{2 s s}}$ was independent of speed for rapidly dehydrated crabs $(P>0.05$; fig. 2 ; table 1$)$.

Maximal Rate of Oxygen Consumption. Mass-specific $\dot{V}_{\mathrm{O}_{2} \max }$ was significantly greater for hydrated crabs than for slowly dehydrated crabs (MannWhitney $U$-test, $P<0.05$; fig 2; table 1 ). Slowly dehydrated crabs exercised at speeds faster than $0.45 \mathrm{~km} \mathrm{~h}^{-1}$ were not able to sustain exercise long enough to reach $\dot{V}_{2 s s}$. Therefore, the $\dot{V}_{\mathrm{O}_{2 s s}}$ at the fastest speed tested $(0.43$ $\left.\mathrm{km} \mathrm{h}{ }^{-1}\right)$ was considered $\dot{\mathrm{V}}_{\mathrm{O}_{2} \text { max }}$. The factorial aerobic scope $\left(\dot{\mathrm{V}}_{\mathrm{O}_{2 m a x}} / \dot{\mathrm{V}}_{2}\right.$ rest $)$ was greater for slowly dehydrated crabs than for hydrated crabs (table 1). However, the large aerobic scope may be attributed to the low $\dot{\mathrm{V}}_{2}$ rest for slowly dehydrated crabs rather than a high $\dot{\mathrm{V}}_{2}$ max. This explanation is also supported by the high ratio of y-intercept to $\dot{\mathrm{V}}_{2}$ rest found for the slowly dehydrated crabs.

Although $\dot{\mathrm{V}}_{2 \mathrm{ss}}$ was independent of speed for rapidly dehydrated crabs, $\dot{\mathrm{V}}_{\mathrm{O}_{2 \max }}$ (averaged for the fastest three speeds) was significantly greater than $\dot{V}_{\mathrm{O}_{2} \text { rest }}$ (Mann-Whitney $U$-test, $P<0.05$; fig. 2 ; table 1 ). The aerobic scope of the rapidly dehydrated crabs was low compared to those found for the hydrated and slowly dehydrated crabs (table 1).

Metabolic Cost of Locomotion. The total metabolic cost of locomotion ( $C_{\mathrm{tot}}$ $=\dot{V}_{\mathrm{O}_{2 s}} /$ speed) for the ghost crab was dependent on speed and hydration state (fig. 3). At all hydration states, $\mathcal{C}_{\mathrm{tot}}$ decreased with an increase in speed, because $\dot{\mathrm{V}}_{2}$ rest and the $y$-intercept became a smaller percentage of the total cost at the higher speeds. The total metabolic cost of locomotion was not

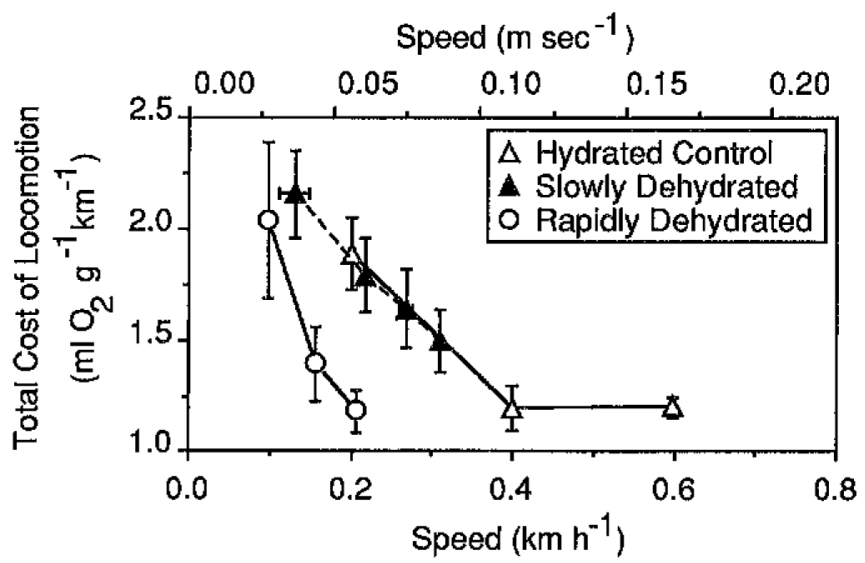

Fig. 3. Total cost of locomotion as a function of speed and bydration state. Rapidly debydrated crabs bad a lower $\mathrm{C}_{\text {tot }}$ than the bydrated controls and slowly debydrated crabs. Error bars represent 1 SE. 
significantly different for hydrated controls and slowly dehydrated crabs, but it was significantly lower for the rapidly dehydrated crabs. The low $\dot{V}_{2 s s}$ for the rapidly dehydrated crabs decreased the total metabolic cost required to move a given distance.

Maximum Aerobic Speed. The slowest speed that elicits $\dot{\mathrm{VO}}_{2 \text { max }}$ is the MAS (John-Alder and Bennett 1981). Slowly dehydrated crabs had the same $C_{\mathrm{min}}$ but a lower $\dot{V}_{2}$ max than hydrated crabs (table 1) and, therefore, attained MAS at a slower speed (fig, 2). The estimated MAS for the rapidly dehydrated crabs, resulting largely from a low $\dot{\mathrm{V}}_{2 \text { max }}$, was $0.20 \mathrm{~km} \mathrm{~h}^{-1}$, which was the slowest MAS of all three groups. The validity of the MAS for the slowly dehydrated crabs and of the estimated MAS for the rapidly dehydrated crabs is supported by endurance data. Endurance times $\left(T_{\text {end }}\right)$ of approximately 15 min at the MAS are typical for most terrestrial runners.

\section{Endurance}

Endurance capacity (time to fatigue) decreased exponentially as exercise speed increased for hydrated, slowly dehydrated, and rapidly dehydrated crabs (fig. 4). Hydrated crabs showed the greatest endurance capacity over the range of speeds tested (where $T_{\text {end }}$ is measured in hours and speed $(v)$ in $\left.\mathrm{km} \mathrm{h}{ }^{-1}, T_{\text {end }}=0.027 v^{-4,66} ; r^{2}=0.84 ; n=16\right)$. The endurance capacity of rapidly dehydrated crabs $\left(T_{\text {end }}=0.046 v^{-1.86} ; r^{2}=0.83 ; n=18\right.$ ) was significantly lower than that of hydrated crabs (ANCOVA model for log transformed data, endurance $=$ constant + temperature + speed; $F_{(1,22)}$ $=10.8, P<0.01)$. Endurance capacities of slowly $\left(T_{\text {end }}=0.026 v^{-2.54} ; r^{2}\right.$ $=0.75 ; n=18$ ) and rapidly dehydrated crabs were not significantly different $\left(F_{(1,36)}=2.6, P>0.05\right.$; fig. 4). However, slowly dehydrated crabs could walk for $2 \mathrm{~h}$, the time limit beyond which data were excluded from analysis, at speeds that could not be sustained for similar periods by rapidly dehydrated crabs. Endurance capacity was correlated with the MAS measured for the hydrated and slowly dehydrated crabs and the MAS estimated for the rapidly dehydrated crabs (fig. 4; table 1).

\section{Discussion}

\section{Evaporative Water Loss}

Rates of EWL for ghost crabs in the present study were similar to rates of EWL found for amphibians of the same body mass (Wygoda 1984) and were twice those measured for other similarly sized, semiterrestrial crab species (Bliss 1968; Herreid 1969b). Herreid (1969b) found that ghost crabs lose 


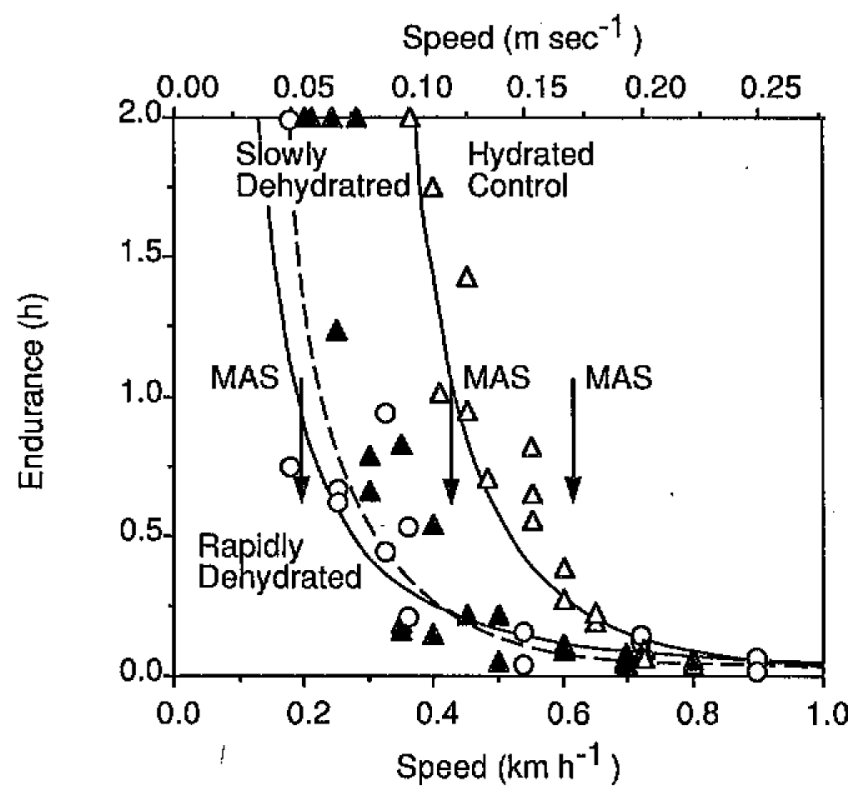

Fig. 4. Endurance time as a function of speed for hydrated controls (open triangles; $\mathrm{n}=17$ ), slowly debydrated crabs (closed triangles, dashed curve; $\mathrm{n}=25$ ), and rapidly dehydrated crabs (open circles; $\mathrm{n}$ = 19). Indurance capacity was correlated with MAS (see fig. 2 and table 1). Hydrated crabs showed greater endurance than debydrated crabs. (Experiments were terminated after $2 \mathrm{~b}$ if the crab bad not yet become fatigued. These data are shown on the graph but were not used for calculation of the endurance equation.)

water at rates more comparable to other semiterrestrial crabs, but the crab's body surface was blotted dry before measurement and half our flow rate was used. Regardless, our EWL rates for the ghost crabs are four times the rate measured for tarantulas and 20 times higher than rates measured for reptiles and the cockroach Periplaneta americana (Herreid 1969b).

The major site contributing to the high water loss in ghost crabs remains uncertain. By coating crabs with petroleum jelly to restrict body surface loss as well as by comparing live and dead animals, Herreid (1969a) suggested that the primary loss was through the general body surface. Although this route is of considerable importance, the present results demonstrate that measurement of $T_{\mathrm{b}}$ is required to interpret EWL data. Water potential differences that drive diffusion from the body surface can be greatly, reduced if evaporative cooling decreases $T_{b}$ below $T_{a}$. Ghost crabs lost more water at $30^{\circ} \mathrm{C}$ than at $24^{\circ} \mathrm{C}$ (air $\mathrm{RH}=40 \%-50 \%$; fig. 1) as predicted by water potential differences based on RH and temperature, with the assumption that $T_{\mathrm{b}}=T_{\mathrm{a}}$. Since $T_{\mathrm{b}}$ was actually equal to $24^{\circ} \mathrm{C}$ when $T_{\mathrm{a}}$ was $30^{\circ} \mathrm{C}$ (see 
Weinstein and Full 1994), the water potential difference was actually smaller, and diffusion alone was unlikely to adequately explain the loss. Respiratoryrelated losses are probable, as is evidenced by substantial water loss even at $100 \% \mathrm{RH}\left(30^{\circ} \mathrm{C}\right.$; fig. 1). After conducting extensive, preliminary measurements of our own, we agree with Greenaway (1988) that comparisons made between coated versus uncoated and live versus dead animals to ascertain the site of water loss are problematic methodologically. Coating crabs does not eliminate all nonrespiratory avenues, and killing crabs may remove the capacity for active regulation of water in the cuticle.

Future isolation of the site of water loss in crabs should lead to testable hypotheses concerning the difference in performance of crabs and amphibians when dehydrated. Ghost crabs and amphibians experience similar rates of water loss (Wygoda 1984). Yet, amphibians can tolerate losing more than $30 \%$ of their initial body mass via water loss before losing their ability to move (critical activity point; Hillman 1978). By contrast, ghost crabs suffer dehydrational death after losing only $14 \%$ of their initial body mass through water loss (Bliss 1968). The difference in sensitivity to dehydration between amphibians and semiterrestrial crabs is just as striking when one considers locomotor performance. The salamander, Pletbodon jordani, shows no decreases in performance (i.e., in maximal rate of oxygen consumption) during induced exercise after $20 \%$ dehydration (Stefanski et al. 1989). The frog, Rana pipiens, experiences a $40 \%$ decline in locomotor performance (i.e., endurance and maximal rate of oxygen consumption) after losing 20\% of its initial body mass via EWL (Gatten 1987; Moore and Gatten 1989). By contrast, the ghost crab experienced a $40 \%$ decline in performance after losing only $3.6 \%$ of its initial body mass (fig. 1 ; table 1 ).

\section{Aerobic Metabolism}

A simple, quantitative model of the effect of temperature on aerobic metabolism during rest and steady state pedestrian locomotion has been created for ectotherms (Herreid, Full, and Prawel 1981; John-Alder and Bennett 1981; Full et al. 1988; Gatten et al, 1992). Our companion study on ghost crabs adds to the thermal model by revealing a potential general pattern at relatively high temperatures (i.e., aerobic metabolism reaches a maximum and declines at the highest body temperatures). However, quantitative predictions at these high temperatures are preliminary, because no simple function is avaflable to describe the decline in aerobic capacity (Weinstein and Full 1994). Likewise, a quantitative, predictive model is also in its earliest stages of development for the effect of dehydration on locomotion. Nevertheless, the present data on ghost crabs do allow, for the first time, general predictions of the effect of dehydration on the direction of change in sub- 
maximal oxygen consumption, the minimum cost of locomotion, maximum oxygen consumption, and maximum aerobic speed during quantified, steady state locomotion in ectotherms.

Resting Oxygen Consumption. The resting metabolic rate of the ghost crab was not affected by rapid dehydration to $3.6 \%$ of initial body weight. Similarly, evaporative water losses up to $30 \%$ of initial body weight have not affected the resting metabolic rate of amphibians (Hillman 1978; Gatten 1987). Slow dehydration in ghost crabs did produce a significant decrease in $\dot{V}_{O_{2} \text { rest }}$ (fig. 2 ; table 1). A reduction in resting metabolic rate after long-term (i.e., days) dehydration has also been observed in other crabs (Wood, Boutilier, and Randall 1986). McMahon and Burggren (1988) note that the cause of the reduction in metabolism during dehydration is unclear. Our data support their speculation that the reduction in $\dot{V}_{O_{2} \text { rest }}$ is not a result of oxygen transport limitation, since slowly dehydrated crabs can increase their oxygen consumption by 13 -fold above this resting rate (fig. 2 ; table 1 ).

Submaximal Oxygen Consumption versus Speed: $y$-Intercept. The predicted oxygen consumption in ghost crabs at the very lowest speeds (y-intercept; fig. 2) did not differ among slowly dehydrated and hydrated animals. By contrast, submaximal oxygen consumption in the rapidly dehydrated crabs was significantly lower than it was in the slowly dehydrated group and appeared to differ from predicted values in the hydrated group (fig. 2). The decreased rates of consumption in the rapidly dehydrated group at the slowest speeds are unlikely to be the result of an oxygen limitation, since oxygen consumption is significantly greater at the highest speed, and since endurance at these slow speeds reached $2 \mathrm{~h}$.

Minimum Cost of Locomotion. The minimum cost of locomotion in ghost crabs was not affected by slow dehydration (fig. 2; table 1). However, for rapidly dehydrated crabs, $C_{\mathrm{min}}$ showed an apparent decrease. The slope of the regression of oxygen consumption versus speed was not distinguishable from zero, primarily because of the difficulty of attaining consistent walking at very slow speeds (table 1 ). The crabs would not walk consistently at treadmill speeds slower than $0.1 \mathrm{~km} \mathrm{~h}^{-1}$. A decrease in the cost of transport in rapidly dehydrated crabs is best supported by comparison of the total cost of transport (i.e., $\dot{\mathrm{V}} \mathrm{O}_{2 s s} /$ speed) at the two slowest sustainable speeds to comparable speeds in hydrated or slowly dehydrated animals (fig. 3). The total cost of moving a $1 \mathrm{~g}$ crab over $1 \mathrm{~km}$ was $18 \%$ lower for rapidly dehydrated crabs relative to hydrated or slowly dehydrated animals exercising at similar speeds. 
Maximal Rate of Oxygen Consumption. The maximal rate of oxygen consumption in ghost crabs decreased by $30 \%$ after slow dehydration and by $70 \%$ after rapid dehydration, even though body mass decreased by only $3.6 \%$ (table 1). By comparison, Stefanski et al. (1989) found no decrease in the maximal rate of oxygen consumption during induced exercise after $20 \%$ dehydration in the salamander, Plethodon jordani. In many amphibians, however, the highest rate of oxygen consumption during unquantified activity does decrease by $42 \%-68 \%$, with up to $30 \%$ dehydration (Gatten 1987 ).

In amphibians, several mechanisms have been proposed to explain the decreased active rate of oxygen consumption that results from dehydration (Gatten et al. 1992). Hillman et al. (1985) identified the steps involved in $\mathrm{O}_{2}$ transport that might limit $\dot{\mathrm{V}}_{2}$ (i.e., ventilation, diffusion at respiratory surface, systemic oxygen transport, and tissue diffusion) and found that systemic oxygen transport is the most likely cause (Hillman 1976, 1980, 1982). Dehydration can decrease blood volume, increase hematocrit, and lead to negative inotropic effects (Bentley and Schmidt-Nielsen 1971; Hillman 1984, 1987; Hillman et al. 1985), which result in cardiovascular "collapse" (Shoemaker 1964). A cardiovascular limitation resulting from dehydration is unlikely in ghost crabs, because the decrease in blood volume is so low and the hemolymph osmolality remains unchanged.

Although alveolar ventilation and pulmonary diffusion appear sufficient in dehydrated amphibians (Withers and Hillman 1983), comparable oxygen transport steps in ghost crabs may be compromised during activity. In addition to gills, land crabs can exchange oxygen through the lining of the branchial chamber, which functions as a lung. Ghost crabs have a heavily folded lining that greatly increases surface area (Diaz and Rodriguez 1977). Diffusion distances of the lining are less than one-tenth that measured in gills (Storch and Welsch 1975). We hypothesize that even a modest dehydration of the branchial chamber lining is likely to impair oxygen uptake. Rapid dehydration may exacerbate the problem, because rehydration or fluid shifts to moisten the lining may have a longer time constraint.

Maximum Aerobic Speed. 'The maximum aerobic speed of ghost crabs decreased by $32 \%$ after slow dehydration and by $68 \%$ after rapid dehydration (table 1). The speed at which $\mathrm{VO}_{2 \text { max }}$ is attained results from the interaction of $\dot{\mathrm{V}}_{2}$ max , the rate of submaximal $\dot{\mathrm{V}}_{2}$ at slow speeds (intercept of the $\dot{\mathrm{V}}_{2}$ vs. speed function), and $C_{\min }$ (Full et al. 1988; Gatten et al. 1992). The primary determinant of MAS in dehydrated ghost crabs was $\dot{\mathrm{V}}_{2}$ max. The effect of slow dehydration on MAS could be explained almost completely by the decline in $\dot{\mathrm{V}}_{2}$ max. The decrease in MAS after rapid dehydration can be accounted for by an interaction of a decrease in $\dot{\mathrm{V}}_{2} \max$ and $C_{\min }$. The 
decrease in $C_{\min }$ (or at least the cost at submaximal speeds; fig. 3) for rapidly dehydrated crabs led to a higher MAS than would result from a decrease in $\dot{V}_{\mathrm{O}_{2} \text { max }}$ alone. Specifically, if the $C_{\text {min }}$ for rapidly dehydrated crabs was the same as for hydrated controls, then the MAS resulting from the decreased $\dot{\mathrm{V}}_{2 \text { max }}$ (it is assumed that there was no change in the y-intercept) would have been only $0.07 \mathrm{~km} \mathrm{~h}^{-1}$ rather than $0.20 \mathrm{~km} \mathrm{~h}^{-1}$ (table 1 and fig. 2). Just as we found in the companion study on temperature (Weinstein and Full 1994), MAS cannot be predicted by $\dot{\mathrm{V}}_{2}{ }_{\text {max }}$ without a consideration of the cost of locomotion.

\section{Endurance}

Actual measurements of endurance capacity reflected the decreases in MAS that accompanied dehydration (fig. 4). Dehydrated crabs had reduced endurance compared to hydrated crabs. Slowly dehydrated crabs could sustain exercise at $0.36 \mathrm{~km} \mathrm{~h}^{-1}$, their MAS, for only $20 \mathrm{~min}$, whereas hydrated crabs could sustain exercise at $0.36 \mathrm{~km} \mathrm{~h}^{-1}$ for over $2 \mathrm{~h}$. At fast walking speeds above MAS, differences in endurance were not significant. At speeds above MAS, additional energy comes from nonoxidative metabolism. A similar pattern has been found in amphibians and reptiles where oxygen consumption is more sensitive to dehydration than is anaerobic metabolism (Gatten 1987; Stefanski et al. 1989). Dehydration decreases endurance capacity in most amphibians (Gatten 1987; Moore and Gatten 1989; Preest and Pough 1989) and reptiles (Wilson and Havel 1989) but does not affect the jumping ability of amphibians (Moore and Gatten 1989) or the sprint performance of reptiles (Crowley 1985).

\section{Effect of Debydration versus Temperature}

Moderate dehydration (present study) and temperature changes (i.e., a decrease in $T_{\mathrm{b}}$ from $24^{\circ} \mathrm{C}$ to $15^{\circ} \mathrm{C}$ or an increase in $T_{\mathrm{b}}$ from $24^{\circ} \mathrm{C}$ to $30^{\circ} \mathrm{C}$; companion study, Weinstein and Full 1994) lead to significant decreases in sustained locomotor performance in the ghost crab, a highly aerobic crustacean (Full and Herreid 1983; Full 1987). Maximum oxygen consumption and maximum aerobic speed decrease by $23 \%-74 \%$, with just a $6^{\circ}-10^{\circ} \mathrm{C}$ change in temperature, and decline by $30 \%-70 \%$, with a dehydration of only $3.6 \%$ of body mass. These decreases substantially reduce sustained perfor mance, since even this highly aerobic crustacean can only sustain a slow walking gait in excess of $2 \mathrm{~h}$ at near optimal temperatures when hydrated (Full and Weinstein 1992).

Dehydration and temperature do not act independently in ghost crabs. Evaporative water loss at low RH results in as much as a $6^{\circ} \mathrm{C}$ cooling of $T_{\mathrm{b}}$ 
below $T_{\mathrm{a}}$. Evaporative cooling prevents the decline in performance associated with an increase in $T_{\mathrm{b}}$ but can result in a decreased performance because of water loss. Our data show that sustained locomotor performance will be most negatively affected when it is hot $\left(T_{\mathrm{a}}=30^{\circ} \mathrm{C} ; T_{\mathrm{b}}=24^{\circ} \mathrm{C}\right)$ and dry ( $\mathrm{RH}=40 \%-50 \%)$ because of the effect of dehydration (i.e., the rapidly dehydrated condition; fig. 2$)$. At cool temperatures $\left(T_{\mathrm{a}}=24^{\circ} \mathrm{C} ; T_{\mathrm{b}}=24^{\circ} \mathrm{C}\right)$ when it is dry $(\mathrm{RH}=40 \%-50 \%)$, water loss rates are lower (fig. 1 ) and performance is increased moderately (i.e., the slowly dehydrated condition; fig. 2). Performance is increased further if the air is humid (RH $=99 \%-$ $100 \%)$, even when the body temperature is high $\left(T_{\mathrm{a}}=30^{\circ} \mathrm{C} ; T_{\mathrm{b}}=30^{\circ} \mathrm{C}\right.$; Weinstein and Full 1994). The maximal performance measured thus far occurs when crabs are the least dehydrated and walk at cool temperatures $\left(T_{\mathrm{a}}=24^{\circ} \mathrm{C}\right)$ equal to their body temperature (Full 1987).

The present results suggest that, all else being equal, the following strategies are predicted to yield the greatest sustained locomotor performance in particular environments. In dry areas ( $\mathrm{RH}<40 \%-50 \%$ ), crabs could increase performance by walking when it is cool $\left(T_{\mathrm{a}}=24^{\circ} \mathrm{C} ; T_{\mathrm{b}}=24^{\circ} \mathrm{C}\right)$, In hot areas $\left(T_{\mathrm{a}}^{*}>30^{\circ} \mathrm{C}\right)$, crabs could increase performance by walking when it is humid ( $\mathrm{RH}=99 \%-100 \%$ ). If a choice is available between performing sustained locomotion in a hot but humid environment versus a cool but dry one, then walking in a hot humid environment will result in relatively greater performance. Alternatively, crabs could maintain high performance even in the harshest environment we examined $\left(T_{\mathrm{a}}=30^{\circ} \mathrm{C} ; T_{\mathrm{b}}=24^{\circ} \mathrm{C}\right.$; RH $<40 \%-$ $50 \%$ ), if they adopted a high water exchange strategy. Evaporative cooling resulting from water loss could decrease $T_{\mathrm{b}}$, and even moderate dehydration could be prevented by frequent and rapid water replenishment. Ghost crabs appear to rely on the latter strategy of high water turnover (Wolcott 1988). Ghost crabs are mostly nocturnal but can forage during the day when temperatures rise (Hughes 1966; Vannini 1976; Wolcott 1978), and some species found in Central America and East Africa are diurnal (Crane 1941; Vannini 1976). Ghost crabs can compensate for high evaporation rates which cool the body by their ability to extract water from interstitial moisture trapped in damp sand (only 5\% water) through hydrophilic setal tufts at the base of the walking legs (Wolcott 1976,1984). Suction pressures can be as low as 76 Torr below ambient pressure and rates of uptake can be rapid $(>1 \%$ body mass $\mathrm{h}^{-1}$; Wolcott 1984). This mechanism of water uptake may restrict their distribution to sandy soils where the water table is close to the surface (Wolcott 1988). Ghost crabs can select soil on the basis of preferred water content by resolving a $1 \%$ difference in soil water content (Warburg and Shuchman 1979). Also, ghost crabs may be excluded from highly organic or impenetrable laterite soil from which water cannot be easily extracted (Wolcott 1984, 1988). 
Examination of the ghost crab has shown that both dehydration and temperature can interact to substantially change the relationships among aerobic capacity, the metabolic cost of locomotion, the speed at maximal oxygen consumption, and endurance during quantified, steady state locomotion. These performance studies set the protocols for future investigations of the mechanism. Moreover, quantifying the capacity for locomotion under controlled laboratory conditions can facilitate the testing of behavioral and ecological hypotheses.

\section{Acknowledgments}

We would like to thank S. Fallejo, B. Lotto, R. Lum, W. Moon, and J. Segal for their assistance in collecting data. We would also like to thank W. KirbySmith for the collection of animals. This work has been supported by a National Science Foundation Graduate Fellowship and Dissertation Improvement Grant DEB-9122559 to R.B.W. and by National Science Foundation Grant IBN-9205844 to R.J.F.

\section{Literature Cited}

BenTLEY, P. J, and K. Schmidi-NIEISEN. 1971. Acute effects of sea water on frogs (Rana pipiens). Comp. Biochem. Physiol. 40A:547-548.

Buss, D. E. 1968. Transition from water to land in decapod crustaceans. Am. Zool. $8: 355-392$.

CRANE, J. 1941. On the growth and ecology of brachyuran crabs of the genus Ocypode. Zoologica 26:145-208.

Crowley, S. R. 1985. Insensitivity to desiccation of sprint running performance in the lizard, Sceloporus undulatus. J. Herpetol, 19:171-174.

Disz, H., and G. RoDriguez. 1977. The branchial chamber in terrestrial crabs: A comparative study. Biol. Bull. 153:485-504.

FuLL, R. J. 1987. Locomotion energetics of the ghost crab. I. Metabolic cost and endurance. J. Exp. Biol. 130:137-153.

Full, R. J., B. D. Anderson, C. M. Finner'Ty, and M. E. Feder. 1988, Exercising with and without lungs. $I$. The effects of metabolic cost, maximal oxygen transport, and body size on terrestrial locomotion in salamander species. J. Exp. Biol. 138:471485.

Fuli, R. J., and C. F. Herreid II. 1983. The aerobic response to exercise of the fastest land crab. Am. J. Physiol. 244:R530-R536.

FulL, R. J., and R. B. WEINSTEIN. 1992. Integrating the physiology, mechanics, and behavior of rapid running ghost crabs: slow and steady doesn't always win the race. Am. Zool. 32:382-395.

GATI'EN, R. E., JR. 1987. Activity metabolism of anuran amphibians: tolerance to dehydration. Physiol. Zool. 60:576-585. 
Gatten, R. E., JR., K. Miller, and R. J. Full. 1992. Energetics at rest and during locomotion. Pages 314-377 in M. E. Feder and W. W. BurgGren, eds. Environmental physiology of the amphibians. University of Chicago Press, Chicago.

GREENAWAY, P. 1988. Ion and water balance. Pages 211-248 in W. W. BURGGREN and B. R. McMaHon, eds. Biology of the land crabs. Cambridge University Press, New York,

HeRREID, C. F., II. 1969 a. Integument permeability of crabs and adaptation to land. Comp. Biochem. Physiol. 29:423-429.

— $1969 b$. Water loss of crabs from different habitats. Comp. Biochem. Physiol. 28:829-839.

Herrejd, C. F., II, R. J. Fuld, and D. A. Prawel. 1981. Energetics of cockroach locomotion. J. Exp. Biol. 94:189-202.

Hillman, S. S. 1976. Cardiovascular correlates of maximal oxygen consumption rates in anuran amphibians. J. Comp. Physiol. 109B:199-207.

- 1978. The roles of oxygen delivery and electrolyte levels in the dehydrational death of Xenopus laevis. J. Comp. Physiol. 128B:169-175.

. 1980. Physiological correlates of differential dehydration tolerance in anuran amphibians. Copeia 1980:125-129.

- 1982. The effects of in vivo and in vitro hyperosmolality on skeletal muscle performance in the amphibians Rana pipiens and Scapbiopus coucbii. Comp. Blochem. Physiol. 73A:709-712.

- 1984. Inotropic influence of dehydration and hyperosmolal solutions on

amphibian cardiac muscle. J. Comp. Physiol. 154B:325-328.
-1987 . Dehydrational effects on cardiovascular and metabolic capacity in two amphibians. Physiol. Zool. 60:608-613.

Hillmai, S. S., P. C. WITHERS, M. S. Hedrick, and P. B. Kimmel. 1985. The effects of erythrocythemia on blood viscosity, maximal systemic oxygen transport capacity and maximal rates of oxygen consumption in an amphibian. J. Comp. Physiol. 155B:577-581.

Hughes, D. A. 1966. Behavioural and ecological investigations of the crab Ocypode ceratopbthalmus (Crustacea: Ocypodidae), J. Zool. Lond. 150:129-143.

JOHN-AlDER, H. B., and A. F. BENNETT. 1981. Thermal dependence of endurance and locomotory energetics in a lizard. Am. J. Physiol. 241:R342-R349.

McMahon, B. R., and W. W. Burggren. 1988. Respiration. Pages 249-297 in W. W. BURGGREN and B. R. MCMAHON, eds. Biology of the land crabs. Cambridge University Press, New York.

MoORE, F. R., and R. E. GATTEN, JR. 1989. Locomotor performance of hydrated, dehydrated, and osmotically stressed anuran amphibians. Herpetologica 45:101-110.

PREeST, M. R., and F. H. POUGH. 1989. Interaction of temperature and hydration on locomotion of toads. Funct. Ecol. 3:693-699.

Scholander, P. F., W. FlaGg, V. WALTER, and L. Irving. 1953. Climatic adaptation in arctic and tropical poikilotherms. Physiol. Zool. 26:67-92.

Shozmaker, V. H. 1964. The effects of dehydration on electrolyte concentrations in a toad, Bufo marinus. Comp. Blochem. Physiol. 13:261-271.

Stefanski, M., R. E. Gatten, JR, and F. H. Poughr. 1989. Activity metabolism of salamanders: tolerance to dehydration. J. Herpetol. 23:45-50.

STORCH, V., and U. WELSCH. 1975. Über Bau und Funktion der Kiemen und Lungen von Ocypode ceratopbthalma (Decapoda: Crustacea). Mar. Blol. 29:363-371. 
TAYlor, C. R., K. SChMid'T-Nielsen, and J. L. RaAB. 1970. Scaling of energetic cost to body size in mammals. Am. J. Physiol. 210:1104-1107.

VANnini, M. 1976. Researches on the coast of Somalia: the shore and the dune of Sar Uanle. X. Sandy beach decapods. Monit. Zool. Ital. Suppl., n.s., 8:255-286.

WARBURG, W. R., and E. SHUChMAN. 1979. Experimental studies on burrowing of Ocypode cursor (Crustacea: Ocypodidae) in response to sand moisture. Mar. Behav. Physiol. 6:147-156.

WEInstein, R. B, and R. J. FulL. 1994. Thermal dependence of locomotor energetics and endurance capacity in the ghost crab, Ocypode quadrata. Physiol. Zool. 67: 855-872.

Weymouth, F. W., J. M. Crismon, V. E. Hall, H. S. Belding, and J. I. Field. 1944. Total and tissue respiration in relation to body weight; a comparison of the kelp crab with other crustaceans and with mammals. Physiol. Zool, 17:50-71.

Wilinams, A. B. 1965. Marine decapod crustaceans of the Carolinas. Fishery Bull. Fish Wildl. Serv. U.S. 65:1-298.

WiLson, B. S., and P. J. Haver. 1989. Dehydration reduces the endurance running capacity of the lizard Uta stansburiana. Copeia 1989:1052-1056.

Wriners, P. C., and S. S. HilLMAN. 1983. The effects of hypoxia on pulmonary function and maximal rates of oxygen consumption in two anuran amphibians. J. Comp. Physiol. 152B:125-129.

WolcotT, T. G. 1976. Uptake of soil capillary water by ghost crabs. Nature 264:756757.

1978. Ecological role of ghost crabs, Ocypode quadrata (Fabricius) on an ocean beach: scavengers or predators? J. Exp. Mar. Biol. Ecol. 31:67-82.

1984. Uptake of interstitial water from soil: mechanisms and ecological significance in the ghost crab Ocypode quadrata and two gecarcinid land crabs. Physiol. Zool. 57:161-184.

—_. 1988. Ecology. Pages 55-96 in W. W. Burggren and B. R. MCMahon, eds. Biology of the land crabs. Cambridge University Press, New York.

WoLcoTT, T. G., and D. L. WolcotT. 1991. Ion conservation by reprocessing of urine in the land crab, Gecarcinus lateralis (Freminville). Physiol. Zool. 64:344-361.

WOOD, C. M., R. G. Boutilier, and D. J. RANDALl. 1986. The physiology of dehydration stress in the land crab, Cardisoma carnifex: respiration, ionoregulation, acid-base balance, and nitrogenous waste excretion. J. Exp. Biol. 126:271-296.

WYGODA, M. L. 1984. Low cutaneous evaporative water loss in arboreal frogs. Physiol. Zool. 57:329-337. 